\title{
Nadine Labaki Sinemasında Kadın Temsili
}

\author{
Emre Aşılıoğlu (Dr. Öğr. Üyesi)
}

iD Mardin Artuklu Üniversitesi Güzel Sanatlar Fakültesi emre.asilioglu@hotmail.com

Mehmet Işık (Doç. Dr.)

iD Mardin Artuklu Üniversitesi Güzel Sanatlar Fakültesi mehmet.isik35@yahoo.com

Başvuru Tarihi: 25.03.2020

Yayına Kabul Tarihi: 27.05.2020

Yayınlanma Tarihi: 24.07.2020

https://doi.org/10.17680/erciyesiletisim.709353

\section{Öz}

Nadine Labaki, Lübnan'ın yetiştirdiği önemli yönetmenlerden birisidir. Eğitimini Lübnan'da tamamlaması ve filmlerini burada yapması, onu diğer Lübnanlı ve Ortadoğulu yönetmenlerden ayırmaktadır. Labaki'nin filmlerindeki kadın temsilinin incelenmesi, kadın sorunlarının genelde Ortadoğu özelde ise Lübnan sinemasında nasıl işlendiğinin ortaya konulması açısından önemli veriler sunar. Bu çalışmada Labaki'nin çektiği üç uzun metraj film olan Karamel (2007), Peki Şimdi Nereye? ve Kefernahum (2018) filmlerinde kadınların ve kadın sorunlarının nasıl temsil edildiği incelenmiştir. Yapılan analizler neticesinde incelenen filmlerin, toplumsal cinsiyet rol kalıplarını ve ataerkil ahlaki normları onayan bir anlatı yapısına sahip olması nedeniyle ana akım sinemaya benzer özellikler taşımakla birlikte; aktif, mücadeleci ve çözümler üreten kadın karakterlere yer vererek ana akım sinema filmlerinden farklılaştığı sonucuna ulaşılmıştır. İncelenen filmlerdeki kadınların genellikle güçlü karakterler olduğu ve çoğu zaman diğer kadınlarla dayanışma içerisinde, birlikte hareket ederek başarıya ulaştıkları; bunun mümkün görünmediği durumlarda kaderlerine razı olmadıkları ve mücadeleyi sürdürdükleri, erkek egemenliğine boyun eğen pasif kadın karakterlerin ise genellikle kaybeden taraf olarak konumlandırıldığı tespit edilmiştir. Ayrıca filmler boyunca ele alınan kadın sorunlarının ekonomik nedenleri üzerinde durulmadığı; sorunların bireyselleștirilerek kolay çözülebilir hale getirildiği belirlenmiştir.

Anahtar Kelimeler: Sinema, Lübnan Sineması, Nadine Labaki, Kadın, Caramel (2007), Peki Şimdi Nereye? (2011) Ve Kefernahum (2018). 


\title{
Represantation of Women in the Cinema of Nadine Labaki
}

\author{
Emre Aşılıoğlu (Asst. Prof. Dr.)
}

Mardin Artuklu University Faculty of Fine Arts

emre.asilioglu@hotmail.com

Mehmet Işık (Assoc. Prof. Dr.)

iD Mardin Artuklu University Faculty of Fine Arts

mehmet.isik35@yahoo.com

Date Received: 25.03.2020

Date Accepted: 27.05.2020

Date Published: 24.07.2020

https://doi.org/10.17680/erciyesiletisim.709353

\begin{abstract}
Nadine Labaki is one of the most significant directors raised by Lebanon. She is distinguished from other Middle Eastern and Lebanese directors because she completed her education in Lebanon and made her films there. Analyzing female representation in Labaki's films reveals important data in terms of explaining how women's problems are handled in the Middle East in general and in Lebanese cinema in particular. In this study, how women and issues of women are represented in Labaki's three full-length films, Caramel (2007), Where Do We Go Now? (2011), and Capernaum (2018) are examined. As a result of the analyses, it is concluded that although the films have similar features with mainstream cinema in that they approve gender role patterns and patriarchal moral codes, they differ from mainstream cinema films in terms of placing emphasis on active, combative, problem-solver female characters. It is determined that the women in the analyzed films are generally strong characters and they often succeed in solidarity with other women by acting together; in cases where this is not possible, they do not accept their destiny, and they struggle; passive female characters who are submissive to male domination are generally positioned as the losing side. In addition, it is determined that the economic causes of women's problems handled throughout the films are not emphasized, and the problems are made easy to solve by individualizing them.
\end{abstract}

Keywords: Cinema, Lebanese Cinema, Nadine Labaki, Woman, Caramel (2007), Where Do We Go Now? (2011), Capernaum (2018). 


\section{Giriş}

Lübnan farklı dini grupların bir arada yaşadığı oldukça kozmopolit bir ülkedir. $\mathrm{Bu}$ kozmopolit yapı ve Hristiyan nüfusun fazlalığı (nüfusun yaklaşık \%40’ı Hristiyan'dır) bir yandan Batı dünyası ile daha yakın ilişkiler kurmasına diğer yandan ise bitmeyen iç çatışmalara zemin hazırlar. Bağımsızlığın kazanıldığı 1943 yılından 1975 yılına kadar nispeten sorunsuz bir dönem geçiren Lübnan, 1975 yılında başlayan ve bir türlü sona ermeyen iç savaş ve çatışmalar nedeniyle adeta kan gölüne döner. Başta bir zamanlar Ortadoğu'nun en önemli finans, ticaret, eğlence ve sanat merkezlerinden birisi olan başkent Beyrut olmak üzere tüm ülke harabeye döner. Önce İsrail'in ardından da Suriye'nin müdahaleleri ve işgalleri ise Lübnan'ın siyasal ve toplumsal yapısı kökünden sarsar. Lübnan, günümüzde de iç sorun ve çatışmalarla başa çıkmaya çalışmaya devam etmektedir.

Bitmek bilmeyen iç çatışmalar ve istikrarsız siyasal yapı, Lübnan sinemasının gelişimini de olumsuz etkiler ve ülkede gerçek anlamda bir film endüstrisinin kurulmasını engeller. 1942 yılına kadar devam eden Fransız işgali ve sansürü ise sinemanın gelişimini geciktirir. Lübnan sinemasının ilk filmi oldukça geç bir tarihte, sinemanın icadından otuz dört yıl sonra, 1929 yılında çekilebilir. İtalyan yönetmen Giordano Pidutti tarafından çekilen The Adventures of Elias Mabrouk (Elias Mabrouk'un Maceraları) adındaki komedi filmi, Lübnan sinemasının ilk filmi kabul edilmektedir. Bir yandan Fransız işgali diğer yandan Mısır sinemasının olağanüstü büyümesi ve Arap film piyasası üzerindeki hâkimiyeti Lübnan`da bir film endüstrisinin kurulma olasılığını ortadan kaldırır (Mouawad, 2020, s. 71).

Bütün bu olumsuzluklara karşın bağımsızlık sonrasında 1950’lerde Lübnan sinemasında bir canlanma yaşanır; ancak bu canlanma kalıcı olmaz. Lübnan filmleri uluslararası sinema festivallerinde gösterilmeye başlar. Georges Nasser'ın Where To (Nereye?) filmi 1957 yılında Uluslararası Cannes Film Festivalinde gösterilir. Michel Haroun, Georges Kahi, Georges Nasser gibi yönetmenler uzun metraj filmler çekerler. Lübnan'ın bu ilk film yapımcıları, konularını Lübnan gerçeklerinden seçerek filmlerinde Lübnan'ın doğal yapısının, köy yaşamının, yerel kıyafetlerinin ve popüler müzik geleneklerinin güzelliğine de vurgu yaparlar. Ancak popüler başarıya giden yolu bulan ve Lübnan'da ticari film endüstrisini kuran öncü yönetmen, Mısır'da eğitim almış ve daha sonra Mısırlı popüler film stillerini yirmi beş yıllık bir süre boyunca çektiği otuz uzun metrajlı filmine son derece başarılı bir şekilde uyarlayan Mohamed Selmane (1923-1997) olur (Armes, 2010, s. 6-7).

Mısır'da film yapımının kamulaştırılmasının yol açtığı aksamaların etkisiyle Lübnan sineması 1960'lı yıllarda altın çağına girer. Mısır Devlet Başkanı Cemal Abdülnasır'ın 1963'te Mısır'daki film endüstrisini kamulaştırmasının ardından aralarında Youssef Chahine gibi önemli isimlerin de bulunduğu birçok özel yapımcı, dağıtımcı ve yönetmen Lübnan'a taşınır (Gugler, 2015, s. 103). Lübnan film endüstrisi, kısa süre içerisinde Arap dünyasının ikinci büyük endüstrisi haline gelir. Beyrut'ta ve Lübnan'ın diğer kentlerinde yeni sinemalar açılır ve sinema seyirci sayısı hızla artar. Bununla birlikte Mısır'a rakip olacak bir film endüstrisi altyapısı kurulamaz (Armes, 2010, s. 7) ve 1975'te Lübnan iç savaşının patlak vermesiyle büyük ölçüde çöker (Mouawad, 2020, s. 71).

İç Savaş, başladığı andan itibaren Lübnan sinemasının en önemli konusu haline gelir ve Lübnan sineması, bundan sonraki otuz yılını büyük ölçüde Lübnan iç savaşını betimlemekle geçirir. 1975 'te iç savaşın başlamasından günümüze kadar geçen zaman 
içerisinde savaş, Lübnanlı sinemacılar için merkezi bir tema olagelir. Savaş sadece sinemada değil; diğer sanat dallarında da en sık işlenen temalardandır. Şiir, resim, müzik, tiyatro ve edebiyat gibi sanatın farklı mecralarında savaşın çeşitli boyutlarını işleyen sanat eserleri üretilir. Sinema, yakın zamana kadar, Lübnan toplumsal belleğinde önemli bir rol oynamaz. Bunun temel nedeni Lübnan'da sinema filmlerinin diğer sanat ürünleri kadar kolay ulaşılabilir olmamasıdır. Sinema filmleri, dağıtım yetersizliği sebebiyle, geniş halk kitleleriyle buluşamaz. Bu durum, bir bakıma savaşın ironisi gibidir: İlgi çeken bir tema olarak savaş, sıklıkla işlenir; ancak onun yarattığı yıkım, filmlerin seyirciye ulaşmasına engel olur. Savaștan önce Lübnan, Arap dünyasında sadece Mısır'ın rekabet edebildiği bir sinema merkezi olarak ün kazanmaya başlamışsa da; bu eğilim savaşın başlamasıyla sona erer ve Lübnan sineması bir endüstriden yoksun çalışan, bağımsız film yapımcıları tarafından üretilen bir film koleksiyonuna dönüşür (Khatib, 2008, s. 21).

Lübnan sineması 1990'ların sonunda yeni bir yükseliş dönemine girer. Lina Khatib Ziad Doueiri'nin "Batı Beyrut" (1998) filmi ile başlattığı bu dönemi, Lübnan'ın sinema "Rönesans"ının başlangıcı olarak görür (Khatib, 2008, s. 21). Bu yeni dönemde yerel sorunlar, Batı estetik anlayıșı ile işlenmeye başlar. Bosta (Philippe Aractingi, 2005), Caramel (Nadine Labaki, 2007), Stray Bullet (Georges Hachem, 2010), Where Do We Go Now (Nadine Labaki, 2011) gibi filmler geniş ilgi görür ve ithal Amerikan filmleriyle yarışır. Halen devam etmekte olan bu yeni dönemin en önemli ve ilginç yönetmenlerinden birisi de Nadine Labaki'dir.

Nadine Labaki; telekomünikasyon mühendisi bir baba ve ev hanımı bir annenin kızı olarak 18 Şubat 1974'de Lübnan'ın Baabdat kentinde dünyaya gelir. Doğumundan bir yıl sonra başlayan ve 1990 yılına kadar devam eden iç savaşın ülkesini harabeye çevirmesine şahitlik eden Labaki, 1993 yılında Beyrut'ta bulunan Saint Joseph Üniversitesi'nde medya bölümünde öğrenime başlar. Öğrenimi sırasında Shari' Bastoor $(1996,12 \mathrm{dk})$ ve 11 Pasteur Street/11 rue Pasteur (1997, 11dk.) isimli iki kısa film çeker (Armes, 2010, s. 99). Bunlardan bitirme projesi olarak çektiği 11 Pasteur Street, 1998 yılında Arap Sineması Bianeli'nde en iyi kısa film ödülünü almaya hak kazanır. Bu filmi ona Fransa yolunu açar ve Fransa'da iki yıl sinema eğitimi alır.

Lübnan'da gelişmiş bir sinema endüstrisi bulunmadığından önce reklam ve müzik kliplerine yönelmek zorunda kalan Labaki (Hornaday, 2012) bu alanda da yetkinliğini ispat ederek 2002 ve 2003 yılında birçok ödüller alır. Özellikle süperstar Nancy Ajram ile yaptığı çalışmalar tanınırlığının artmasını sağlar ve onu Lübnan'ın ve Ortadoğu'nun önce gelen klip yönetmenlerinden birisi haline getirir (Ginsberg ve Lippard, 2010, s. 243). Aynı zamanda oyunculuk da yapan Labaki, Philippe Aractingi'nin The Bus'1 (2005) ve daha yakın zamanda çekilen Georges Hachem'in Stray Bullet'i (2011) de dahil olmak üzere birçok önemli filmde rol alır (Armes, 2015, s. 232).

Nadine Labaki, üniversite dâhil tüm öğrenimini ve kariyerini Lübnan'da sürdürmesi ve genel Lübnan Sineması perspektifinden farklı filmleriyle özgün bir yere sahiptir. 0, 2000'li yılların sadece ülkesinde çalışan Ortadoğulu tek kadın sinemacıdır (Armes, 2015, s. 13). Bu çalışmada bu önemli yönetmenin filmlerindeki kadınların ve kadın sorunlarının temsili incelenmektedir.

\section{Yöntem}

Gelişmiş Batı toplumları da dahil olmak üzere kadınlar, erkeklere nazaran oldukça dezavantajlı bir durumdadır. Bu dezavantajlı durumun sürmesinde toplumsal cinsiyet 
rol kalıplarının etkisi büyüktür. Toplumsal cinsiyet (gender), kadın ya da erkek olmanın biyolojik yönünü ifade eden cinsiyet kavramından farklı olarak toplumun ve kültürün kadın ya da erkek olmaya yüklediği anlamları ve beklentileri ifade eder (Stoller, 2020, s. 9-10). Toplumsal cinsiyet olgusu aile, ekonomi, hukuk, politika gibi toplumsal örgütlenmelerde yapılanır, kadın ve erkeğe atfedilen rolleri toplumun görmek istediği şekilde ve var olan ideoloji doğrultusunda tanımlar. Söz konusu roller durağan olmayıp zaman içinde sürekli olarak değişime uğrar (Erus ve Gürkan, 2012, s. 207); başka bir ifadeyle yeniden ve yeniden üretilir.

Sinema da kadın ve erkek arasındaki eșitsiz ilişkilerin devamına hizmet eden toplumsal cinsiyet rol kalıplarının, yeniden üretiminde önemli bir araç olmakla birlikte bunların sarsılmasına ve daha eşitlikçi bir düzenin kurulmasına yönelik çabalara yardımcı olma potansiyelini de bünyesinde taşır. Son yıllarda birçok bağımsız yönetmen, toplumsal cinsiyet rol kalıplarını sorgulayan ve sarsmaya çalışan filmler çekmektedir. Özellikle gelişmiş Batı ülkelerinde sinema yapan bağımsız yönetmenler, kendi ülkeleri yanında dünyanın farklı coğrafyalarındaki kadınların yaşadığı sorunları ve maruz kaldıkları ayrımcılığı işleyen çok sayıda film çekmektedir. Kadın erkek eşitsizliğinin ve buna ilişkin sorunların en yoğun coğrafyalardan birisi de Ortadoğu'dur.

Kadınların toplumsal hayatın her alanında çeşitli ayrımcılıklara maruz kaldığı Ortadoğu coğrafyasında kadın sinemacı sayısı da oldukça azdır. Eğitim imkânlarının sınırlılığı ve toplumsal hayatın hemen her alanında kadınların önünü tıkayan toplumsal cinsiyet eşitsizliği, nitelikli yönetmenlerin yetişmesine engel olmaktadır. Bununla birlikte Lübnan kozmopolit yapısının ve Batı dünyasıyla geliştirdiği yakın ilişkilerin etkisiyle kadın yönetmen sayısının diğer Ortadoğu ülkelerine nazaran fazla olduğu bir ülkedir. Heiny Srour (1945-), Jocelyn Saab (1948-2019), Randa Chahal Sabag (1953-2008), Joana Hadjithomas (1969-), Danielle Arbid (1970-), Eliane Raheb (1972-), Nadine Labaki (1974-) Lübnanlı kadın yönetmenlerden ilk akla gelenlerdir. Bu yönetmenler içerisinde en dikkat çekeni özellikle Kefernahum filmi ile tüm dünyada büyük ilgi çeken Nadine Labaki'dir. Diğer Lübnanlı yönetmenlerden farklı olarak üniversite dâhil tüm eğitim kariyerini Lübnan'da tamamlamış olması ve filmlerini kendi ülkesinde çekmesi onu özgün kılmaktadır.

$\mathrm{Bu}$ çalışmada amaç yönetmenliğini Nadine Labaki'nin yaptığı filmlerde kadınların ve kadın sorunlarının nasıl temsil edildiğini ortaya koymaktır. Bu çerçevede Labaki'nin yönetmenliğini yaptığı üç uzun metraj filmin -Karamel (2007), Peki Şimdi Nereye (2009) ve Kefernahum (2018) ideolojisi, söylem analizi yöntemiyle çözümlenmiştir. Oluşturulan çözümleme çerçevesi içerisinde, anılan üç filmdeki kadın karakterlerin özellikleri incelenerek bu karakterlerin erkekler ve diğer kadınlar karşısında nasıl konumlandırıldığı ve yaşadığı sorunların nasıl temsil edildiği ortaya konulmuştur. Kameranın politik bir araç olduğu göz önüne alınarak incelenen filmlerin yüzeysel anlamlarından ziyade derin anlamlarına odaklanılmıştır. Sinema ideolojik üretimin önemli araçlarından birisidir. Ancak bu yalnızca egemen sınıfın hegemonya kurmasına hizmet eden bir araç olduğu anlamina gelmez. Daha seyrek de olsa filmlerde alternatif temsillere de yer verilir. Filmlerin ideolojisinin daha çok içerdikleri tezlerde, kullanılan somut temsil stratejilerinde ve yarattıkları muhtemel etkilerde aranması gerektir (Ryan ve Kellner, 2010: 19). Bu kapsamda bu çalışmada filmlerin tezleri ve somut temsil stratejileri her film için ayrı ayrı incelenmiş ve bunların genel bir değerlendirmesi yapılmıştır. Ayrıca filmlerde anahtar temaların nasıl geliştirildiğini görmek ve söylemin yoğunlukla hangi 
temalar etrafında geliştirildiğine ilișkin ipuçları elde etmek amacıyla (Dursun, 2001: 203) tematik analizden yararlanılmıştır.

\section{Bulgular}

\subsection{Karamel Filminin Çözümlenmesi Sonucunda Elde Edilern Bulgular}

Nadine Labaki'nin ilk uzun metraj filmi olan Karamel, Lübnan sinemasında İç Savaş dışında bir konuyu ele alan nadir başarılı filmlerden birisidir. İşlediği konu ve bu konuyu ele alış biçimiyle genel Lübnan filmleri örnekleminden ayrılır. Film, barış döneminin iyimser havasında, bir güzellik salonunda çalışan bir grup kadın ile onların çevresindeki kadınların yaşam öykülerinden kesitler sunar. Film boyunca "yaşları geniş bir yelpazede yer alan ve farklı sosyal/dini geçmişlere sahip bu kadınlar" (Balaa, 2019, s. 430), birbirleriyle dayanışma içerisinde çeşitli bireysel sorunlarının üstesinden gelmeye ve hayata tutunmaya çalışır.

Farklı dini toplulukların birlikte yaşaması, Lübnan'ın ayırıcı özelliklerindendir. Bu özellik onun diğer Orta Doğu ülkelerine göre batı ülkeleri ile çok daha sıcak ilişkiler geliştirmesine yardımcı olur ve Lübnan halkını, diğer Arap toplumlarına göre daha az muhafazakâr kılar. Lübnanlı kadınların medya organlarında veya sosyal yaşantıda çok daha görünür ve özgür olabilmelerinin de bundan kaynaklandığı düşünülmektedir (Cestor, 2010, s. 103). Lübnan'da kadınların durumu, her ne kadar diğer Arap ülkelerinden daha iyi olsa da, çok da iç açıcı değildir. Lübnan kadınlarının sorunlarına farklı bir pencereden bakan Karamel, işlediği konu ve anlatı yapısıyla Lübnan sinemasının en ilginç filmlerinden birisidir. Savaş sonrası Lübnan'ın ya da Lübnan kadınının yașadığı gündelik sorunlar gibi daha klasik bir konu yerine kadın cinselliğinin sorunsallaştırılması ve bu konunun işlenmesi için romantik komedi türünün tercih edilmesi, onu diğer filmlerden farklılaştırır.

Filmin adını aldığı "karamel", kadınların ağda yapmak için kullandıkları bir macuna gönderme yapar. Ağda, kadınların gündelik hayatında önemli bir yere sahip olan ve geleneksel kabul edilebilecek ataerkil estetik normları onaylayan bir etkinliktir. Ancak yönetmenin ağda etkinliğini sunuş șekli, ona tam tersi bir anlam yükler ve ağdayı temel ataerkil estetik normlara karşı bir başkaldırı ritüeli haline getirir. Labaki, bir güzellik salonunu filmin ana mekânı yaparak karakterlerini, Beyrut ve Lübnan'ın sosyal ve siyasi zeminden uzaklaştırıp modern toplumun mikro kozmosunun birer parçası haline getirir. Kadınların film boyunca işlenen sorunları, dünyanın farklı coğrafyalarında yaşayan kadınların bireysel problemleri ile paralellik gösterebilecek niteliktedir. Film, kadınların gündelik yaşamlarının, sorunlarının ve endişelerinin, ne kadar evrensel olduğunu ortaya koyar.

Karamel, Beyrut'ta güzellik salonunda süregiden gündelik hayatın içerisinden çekilip alınmış, gerçeklik kaygısı olan bir filmdir. Film, ağdanın yapımında kullanılan malzemelerin bir araya getirilmesini gösteren bir sekansla açllır. Ağdanın altın renkli, lezzetli, baştan çıkarıcı görüntüsünün içerisinde barındırdığı büyük acı ile güzellik salonunda bir araya gelmiş beș ana kadın karakterin yaşamları arasında eğretilemeli (metaforik) bir ilişki söz konusudur. Kadın karakterlerin ilk bakıșta mutlu ve uyumlu görünen yaşamları ile ağdanın baştan çıkarıcı görüntüsü arasında paralellik vardır. Kadınların her birinin mutlu görünen yaşamları da aslında acılarla doludur. 


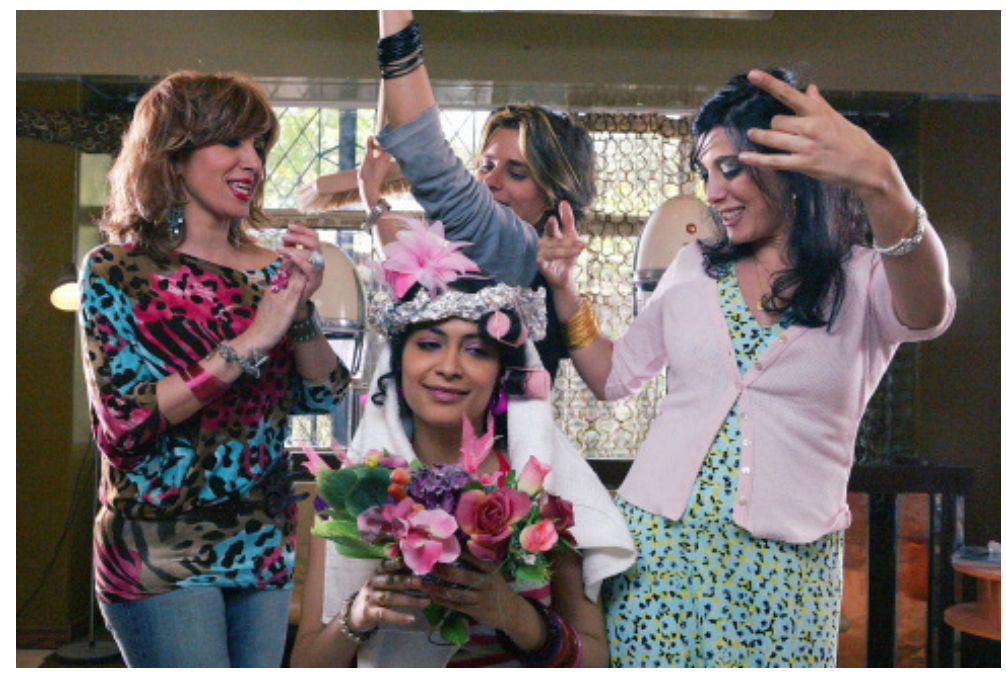

Görsel 1: Nisrine Karakterinin Saçının Yapıldığı Sahne

Smith'e (1993) göre kadınlar sinemada geleneksel toplumsal cinsiyet rollerine uygun şekilde temsil edilirler. Filmler yoluyla kadının, anne ve eş olma sorumluluğu yeniden üretilir. Sinemada toplumsal cinsiyet rolleri ev işleri ile ilgilenmek, çocuk büyütmek veya bir erkeği sevmek gibi bir takım temalar etrafında kümelenir. Bu temalar ile saygınlık kazanmak, kahramanlık gibi kavramlar ilişkilendirilerek bir kadın imgesi inşa edilir. Labaki'nin filminde ise geleneksel kadın imajının dıșında kadın karakterlere yer verildiği görülmektedir. Filmin beş ana kadın karakteri de bekârdır ve hiç birisi çocuk sahibi değildir. Bununla birlikte beș kadın karakter de istemedikleri halde son kertede toplumsal cinsiyet rol kalıplarına uygun hareket ederler.

Filmde; güzellik salonu başlı başına ideoloji yüklü bir mekândır. Nitekim toplumsal yapı ister ilerici ister geleneksel özelliklere sahip olsun güzellik salonu, kadınlar için önemli bir sosyalleşme mekânıdır. Kadınlar burada gündelik yaşamlarının en özel anlarına ilişkin deneyim ve görüşlerini paylaşırlar. Bununla birlikte kadın ve erkek eşitliğinin sağlandığı toplumlarda güzellik salonu; kadının kendisinden şüphe duyduğu, varoluşsal değerlerinden vazgeçtiği bir alan olarak görülebilir. Komşuluk, arkadaşlık gibi ilişkilerle örülmüş Karamel filminin güzellik salonu ise, kadınlara fiziki olarak dokunulmadan önce; müşterilerin ve çalışanların gülme, ağlama, sohbet etme ya da en azından duygularını saklama gereği duymadan ifade etme gereksinimlerini karşılayabildikleri bir mekândır. Ve bu haliyle kadınların duygularına hitap eden bir çeşit sığınak işlevini yerine getirmektedir. Güzellik salonu süslenmek için gidilen bir yerin ötesinde kadınların kendisini açıkça ifade edebildiği, bir birlerinin sorunlarını paylaşabildikleri bir özgürleşme alanı olarak karşımıza çıkar. Güzellik salonları her ne kadar genel olarak rekabet ve dedikodu ile ilişkili mekânlar olarak algılansa da; filmde yer alan salon, kadınların birlikte gülebildiği, ağlayabildiği veya en azından duygularını ifade etmekten çekinmedikleri bir alan olarak tasarlanmıştır (Taubin, 2008, s. 70). Ancak son kertede güzellik salonuna gelen kadınların kendilerinden çok erkekler için süslenmesi, mekânın eleştirelliğini zedelemektedir. 


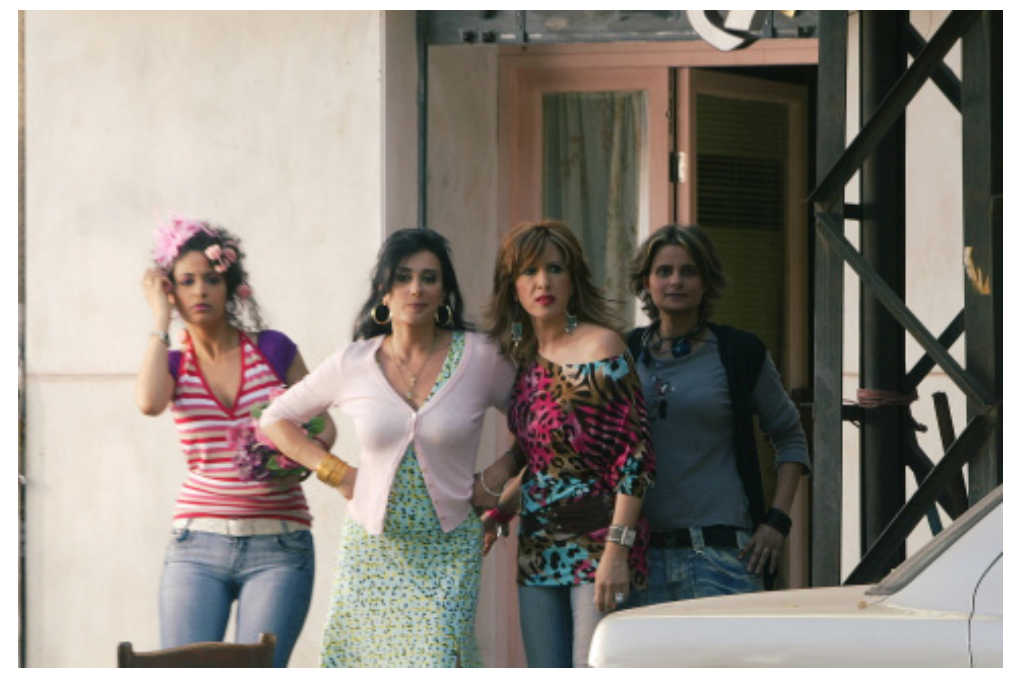

Görsel 2: Layale, Nisrine, Rima, Jamale Salonun Dışında Yaşanan Olayı İzliyor

Karamel, Beyrut'ta yaşayan beş Lübnanlı kadının gündelik yaşamına odaklanır. Bunlardan Labaki'nin canlandırdığı Layale kuaför salonun sahibi olarak karşımıza çıkar. Evli bir erkekle ilişkisi olan Layele, bu ilişki sebebiyle suçluluk duymakta; ailesinden utanmaktadır. Erkek arkadaşının kendisine beklediği değeri vermediğini fark etmesiyle birlikte ilişkisini sorgulamaya başlar. Bu arada erkek arkadaşının eși ve kızıyla tanışır ve ilişkisini sorgulamak zorunda kalır. En sonunda da ilişkisini bitirir. Böylece ataerkil düzenin ahlaki kodlarına uygun davranmış olur.

Nisrine (Yasmine Al Massri) bir diğer önemli kadın karakterdir. Muhafazakâr bir ailenin gelini olmaya hazırlanan Nisrine, daha önce bașka bir erkekle birlikte olduğu için ailenin ve kocasının tepkisinden çekinmektedir. Arkadaşları bu tepkiden kurtulmak için Nisrin'e düğün gecesi çarşafa güvercin kanı dökmesini önerirler. Daha sonra bu plandan vazgeçilir; bunun yerine cerrahi bir operasyonla ilk gece yaşanabilecek bir olumsuzluk riski ortadan kaldırılır. Burada önemli olan nokta, çözümün bulunup bulunmaması değil; kadının böylesi bir toplumsal baskıya maruz kalarak, dertten derde koşması, kendini yiyip bitirmesi; ancak daha da önemlisi, başta eşi olmak üzere ailesine ve çevresindekilere yalan söylemek zorunda kalmasıdır. Ayrıca filmde sunulan çözüm biçimi oldukça alt üst edicidir. Modern dünyada bilim gelenekleri aşındırmakta ve onları anlamsızlaştırmaktadır. Sağlık alanındaki ilerlemeler, "bekâret" gibi oldukça katı bir geleneği dahi aşındırmış, sadece görünürde yerine getirilmesi mümkün ve basit bir tıbbi müdahale ile aşllabilecek bir norma dönüşmüştür.

Rima (Joanna Moukarzel), kuaförde çalıșan kadınlardan bir diğeridir. Kuaför salonuna daha sık gelmeye başlayan güzel bir müşteriden etkilenir ve ona yakınlaşır. Rima, bir kuaför salonunda çalışmasına rağmen kısa saçlıdır. Ayrıca ağda yapmak, etek giymek gibi kadınlara özgü giyim pratiklerini reddetmektedir. Rima karakteri, toplum için bir ötekidir. Duygularını ve cinsel kimliğini sadece kuaförde, örtük şekilde açığa vurmaktadır. Cinsel yönelimi, diyaloglar aracılığı ile vurgulanmasa da bakışları, gülüşü ve sessizliği ile izleyiciye sezdirilir. Bununla birlikte Rima da diğerleri gibi kritik anlarda geleneklere ve toplumsal cinsiyet rol kalıplarına uygun hareket etmek zorunda kalır ve Nisrine'nin düğününde diğer arkadaşlarının baskısı ile etek giyer, ağda ve makyaj yapar.

Filmin ellili yaşlardaki kadın karakteri Jamale ise hem toplumsal baskılarla hem de yaşlanmanın getirdiği sorunlarla baş etmeye; bunları bir şekilde gizlemeye çabalar. Menopoza girdiği ve artık adet görmediği halde kendisini hala adet görüyor gibi 
göstermeye çalışan Jamale, gözünün etrafında oluşan çizgileri de makyajla gizlemeye çalışır. Kadının biyolojik olarak doğurgan olabilmesi ile eril hâkimiyet arasında yakın bir ilișki bulunur. Bir başka ifadeyle pek çok kültürde menopozla birlikte kadınların toplumsal konumları radikal bir şekilde değişir (Bayraktar ve Uçanok, 2002). Özellikle belirli bir gelişmişlik düzeyinin altındaki toplumlarda menopoz, kadının artık temel "görevini" yerine getiremediği anlayışını da beraberinde getirdiği gibi, eğer kadın bir koca veya erkek çocuk gibi onu koruyabilecek bir güçten yoksunsa, onun toplumdan dişlanmasına ya da toplum tarafından tehlikeli görülmesine neden olabilir (Héritier, 2013, s. 17).

Rose (Sihame Haddad) karakterinin öyküsü ise fedakâr olmakla yükümlü orta yaşını hayli geçmiş bir kadının hikâyesidir. Küçük ve eski bir dükkânda terzilik yaparak hayatını geçiren Rose, güzel olmak, aşk yaşamak istemektedir. Ancak yaşlanmıș annesine baktığından buna zaman ve emek harcayamamaktır. Kendisi gibi orta yaşını aşmış bir müşteriye âşık olmasıyla bütün yaşamı alt üst olur. Bu gizli ve uzaktan yaşanan aşktır ve Rose'u büyük bir ikilem içerisine sokar. Ya annesine bakma sorumluğuna devam edecek ya da kadınlığını yaşamayı, âşık olduğu adamla mutlu bir yaşam kurmayı seçecektir. Rose, yaşadığı büyük aşka rağmen tercihini sorumluluklarına devam etmekten yana kullanır ve hazırlandığı halde sevdiği adamla buluşmaya gitmez. Böylece o da filmin diğer kadın karakterleriyle benzer şekilde ataerkil düzenin kadına biçtiği toplumsal cinsiyet rol kalıplarına uygun davranmıș olur.

Gündelik yaşamdakine paralel şekilde sinemada da erkek aktif yani seyreden; kadın ise pasif yani seyredilen olarak temsil edilir. Böylece aktif olan erkeğin bakışı, onun bakışına uygun fantazyaya göre kadın figürüne aktarılır. Bir bașka ifadeyle kadınlar geleneksel teşhirci rollerde kurgulanarak hem erkek tarafından bakılması gereken imgeye dönüşür hem de teşhir edilirler (Mulvey, 1997). Temel karakter olduğu durumlarda dahi kadın edilgen, güzel, gizemli, şaşkın, anlaşılması güç bir varlık olarak ele alınırken; yan karakterlerde erkeğin tamamlayıcısı olarak konumlandırılır. Güçlü kadın imgesinin çizildiği örneklerde ise "ıstırap, hırs, aç gözlülük ve şevket düşkünü" türünden olumsuz nitelemeler yüklenerek ele alınır (Smith, 1993, s. 19). Geleneksel sinemanın bu özelliklerine karşın Karamel, erkek karakteri sürekli gölgede bırakarak kadınları aktif, erkekleri ise pasif şekilde konumlandırır. Bununla birlikte kadınların kendileri için değil, erkekler için süslenmesi, filmin eleștirelliğini ciddi şekilde zayıflatır.

Film boyunca genç kadınların eğlenmesi, giyinip kuşanması, süslenmesi erkek bakışına yönelik unsurlar olarak karşımıza çıkar. Bu sahneler kadın bakışıyla sıradan ve gündelik hayat görüntüleri olarak sunulabilecekken daha çok röntgenci erkek bakışına sunulan destansı anlar olmaktan öteye gidemez. Nisrine'nin düğünü öncesinde, kuaförde, Rima'ya birlikte, makyaj yaptıkları sahnede, süslenmenin erkek beğenisinden ziyade kadınların birlikte keyfini çıkardıkları ve paylaştıkları bir durumun anlatısına dönüşmesine karşın (İnceoğlu, 2015, s. 92) nihai amacın Rima'nın ataerkil estetik normlara uygun bir görünüme kavuşturulması olması, filmi ataerkil düzeni onayan bir anlatıya dönüşür.

Mulvey'e (1997) göre geleneksel sinemada kadın karakterler ya temsil ettikleri değerlerle ya da erkek karakterlerin eylemlerinde tahrik edici unsur olarak bulunmalarından dolayı önemlidirler. Böyle yapımlarda kadın kahramanlar içerisinde bulundukları durumlarla veya yaşadıkları çeşitli duygularla erkek kahramanların eylemlerinin veya tutumlarının mantıksal açıklamaları olurlar. Ancak Labaki'nin Karamel filminde böyle bir anlatı söz konusu değildir. Karamel'in merkezinde erkekler değil; kadınlar vardır. Kadınların gündelik yaşamı ve sorunları ön plandadır. Erkek karakterlere çok az yer verilmiştir. 
Geleneksel sinemanın aksine Labaki'nin filminde erkek karakterler kadın karakterin eylemlerinin veya tutumlarının rasyonel temelleri olarak işlev görürler.

\subsection{Peki Şimdi Nereye? (Where Do We Go Now?) Filminin Çözümlenmesi Sonucunda Elde Edilen Bulgular}

Nadine Labaki'nin yönetmenliğini ve oyunculuğunu yaptığı bir diğer film olan Peki Şimdi Nereye Lübnan'da Müslüman ve Hristiyanların yüzyıllardır birlikte yaşadıkları küçük bir köyde yaşanan olayları konu alır. Bir röportajında filmi hamile olduğu sırada, Beyrut'da yine bombaların patladı̆̆ı bir günde çekmeye karar verdiğini dile getiren Labaki, "yıllarca aynı apartmanı paylaşan, beraber büyüyen, aynı okula giden insanların bir anda birbirlerine düşman kesilmelerinin tek nedenin aynı dine inanmamaları" olmasının kendisini derinden sarstığını ifade eder. Bir oğlu olması halinde onu bu kargaşadan nasıl uzak tutabileceğini, "onun ailesini, dinini, yaşadığı evi koruma güdüsünü nasıl engelleyeceğini” düşündüğünü ve bu sorgulamaların kendisini Peki Şimdi Nereye’yi çekmeye yönlendirdiğini belirtir (Labaki, 2012):

Film, köyün Müslüman ve Hristiyan kadınlarının birlikte gerçekleştirdikleri etkileyici bir mezarlık ziyareti sekansı ile başlar. Müslüman ve Hristiyanların mezarları yan yanadır ve iç savaşta ölen genç erkeklerle doludur. Kimisi eşini, kimisi oğlunu ziyaret etmektedir. Kadınlar karşıt kamplarda yer almalarına ve sevdiklerini kaybetmiş olmalarına karşın barış içerisinde yașamaktadırlar. Ancak bu kırılgan bir barıștır ve bütün kadınlar barıșın bozulmasından endişe etmektedir.

Nitekim korkulan olur ve Lübnan'ın Wardeh bölgesinde yaşanan din temelli çatışmalar, köyde yaşayan erkekler arasında çeşitli gerginliklerin başlamasına zemin hazırlar. Uzunca bir süredir birlikte yaşayan barış içinde yaşayan köyün erkekleri bu gerginlikten etkilenerek her firsatta birbirlerine saldırmaya başlarlar. Buna karşın filmin kadın karakterleri ise köyün imamını ve papazının da desteğini alarak barışın bozulmaması için büyük çaba gösterirler. Yaşanabilecek çatışmaların engellenebilmesi için film boyunca çeşitli fedakârlıklar gösterirler ve köyün erkeklerini çatışmadan uzak tutarak korumaya çalışırlar: Köyde bulunan tek televizyondan çatışma haberlerinin izlenmesini engellemeye çalışırlar, köye gelen gazeteleri yakarlar, köye pavyonda çalışan kadınları çağırarak erkeklerin çatışmaya dönük ilgilerini başka yöne çekmeye çalışırlar, hatta filmin sonlarına doğru topluca din değiștirirler.

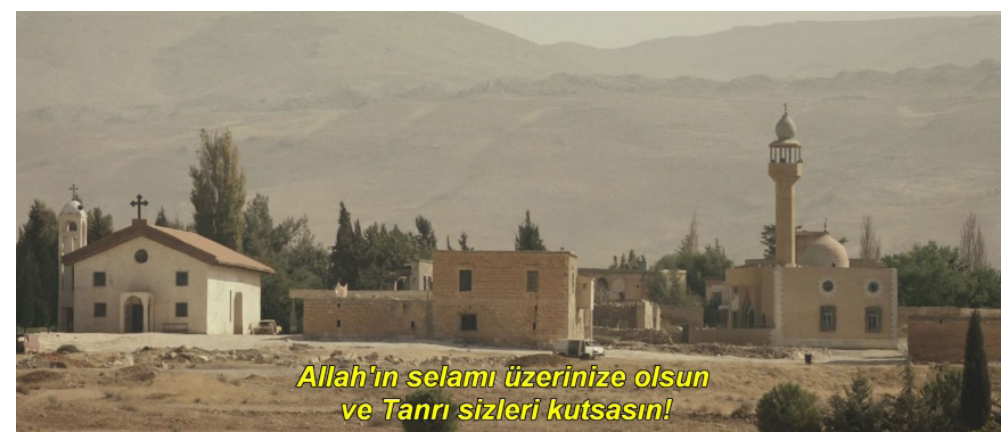

Görsel 3: Köyün Cami ve Kilisesi Aynı Kadrajda

Sinemada savaş genellikle cesaret, kahramanlık, dostluk, koruyuculuk, fedakârlık gibi hegemonik erkeklik değerleriyle yakından bir ilişkili bir olgu olarak sunulur. Özellikle Hollywood sinemasında sıklıkla ele alınan II. Dünya Savaşı, Vietnam, Kore, Afganistan, Irak gibi savaşlarla ilgili filmlerde anılan değerlerin sürekli üretildiği ve yeniden üretildiği söylenebilir. Bu tür yapımlarda; savaşla birlikte vurgulanan vatanseverlik, özveri, 
fedakârlık gibi kavramlar, erkek perspektifli bir bakış açısıyla sürekli ön planda tutularak ele alınır ve izleyicinin bu duygularını devindirmeyi amaçlar (Demir, 2008, s. 177). Labaki'nin Peki Şimdi Nereye? filmi ise ana akım sinemanın aksine; savașın anlamsızlığını vurgulayarak hem hegemonik erkeklik değerlerini sorgulamaya açar hem de barışın tesisinin ancak kadınlar eliyle mümkün olabileceği tezini savunur. Labaki, bu filminde egemen sinema dilinin aksine erkekleri değil kadınları kurtarıcı olarak konumlandırır.

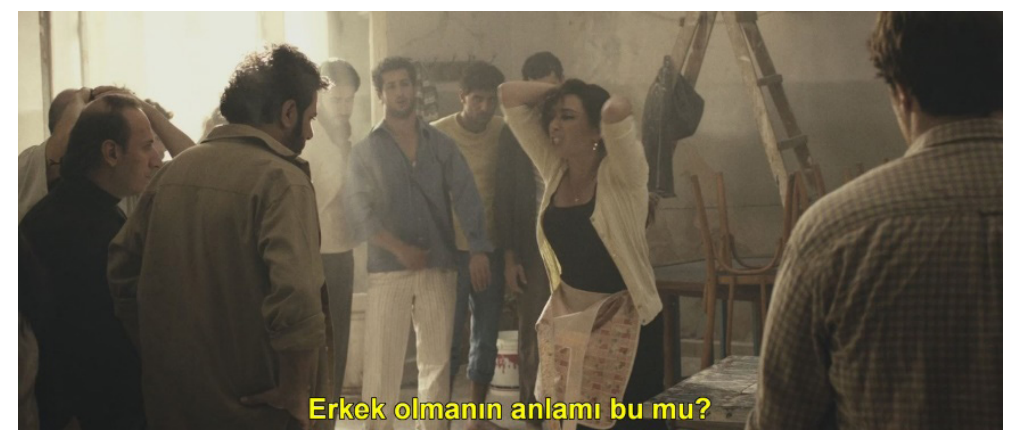

Görsel 4: Köyün Erkekleri Arasında Yaşanan Kavgayı Durdurmak İçin Amale'in Araya Girdiği Sahne

Geleneksel anlatı yapısına sahip filmlerin pek çoğunda kadının toplum içinde değerinin en önemli göstergesi olarak annelik sunulur. Bir başka ifadeyle geleneksel olarak konumlandırılmış kadın imgesi, bu filmler aracılığıyla yeniden üretilir. Çeşitli mücadelelerin hüküm sürdüğü erkek dünyasına karşı kadın dünyası, düzeni temsil eden, sevgi ve daha uygar bir yapıda sunulur. Kadın karakterlere düşen; maceraya, bilinmezin araştırılmasına, engelleri aşıp ödüllere ulaşmaya gönül vermiş erkeğin, yuvanın temsil ettiği düzene ve kurallı yaşama geri dönmesini ya da sınavlar aracılığıyla erkeklik niteliklerine sahip olduğu kanıtlandıktan sonra, aile/evlilik ortamının sıcak ve uyumlu atmosferine kavuşmasına aracılık etmektir (Abisel, 2005, s. 296). Bu kurgu içerisinde erkeğe, cesaret, bilgelik, kahramanlık, akıl gibi çeşitli erdemler yüklenirken kadınlara aşırı duygusallık, güçsüzlük gibi tersi özellikler atfedilir (Akyön, 2014, s. 23). Peki Şimdi Nereye? filminde kadınlar, daha cesur, bilge ve akıllı iken erkekler irrasyonel ve duygusaldır. Erkeklerin duygusallığı ve öfkelerini kontrol edememeleri, köyü başlaması halinde birçok insanın hayatını kaybetmesi muhtemel bir iç savaşın eşiğine getirir.

Filmin girişinde "kaderin ellerine bırakılan kadınlar" ifadesi geçmektedir. Ancak bu ifade, büyük ölçüde Peki Şimdi Nereye? filminin kadın karakterinin özellikleri ile zıtlık oluşturacak niteliktedir. Çünkü filmde yer alan kadın karakterler aslında pasif değil aktif olarak kurgulanmıștır. Bir başka ifadeyle film boyunca yaşanması muhtemelen çatışmadan kaçınmak için verilen mücadele ile olaylara yön veren kadınlardır. Onlar her ne kadar belli bir kadere mahkûm edilmiş gözükseler de, bu kaderden kurtulmak için ellerinden geleni yapan, sadece izleyici olarak mahkûm kaldıkları kaderi yaşamının ötesinde bunu değiștirmek için mücadele eden bireyler olarak ön plana çıkarlar.

Peki Şimdi Nereye? filminin kadınları genel olarak birbirlerinden farklı kişisel özelliklere sahip olsalar da benzer toplumsal ve sınıfsal özellikler gösterirler ve savaş karşısındaki tavırları ortaktır. Kadınlar, savaşı engellemek uğruna bireysel farklılıklarını ve kişisel çatışmalarını bir kenara bırakarak ortak bir mücadeleye girișir. Onları barıșa rehberlik etme özellikleri taşıyan, yaratıcı kadınlar olarak tanımlamak mümkündür. Olası çatışmaları engellemek için eğlence sektöründe çalışan bir grup Ukraynalı kadını köylerine davet ederler, televizyonda çatışma haberlerinin izlenmesinin önüne geçebilmek için yapay tartışmalar çıkarırlar, belediye başkanın eşine Hz. Meryem ile konuştuğu söyletirler. 
Film boyunca sıklıkla karşımıza çıkan Hz. Meryem ikonları, farklı din ve mezheplere mensup Lübnan kadınlarının çektiği acıların müşterekliğine göndermede bulunur. Hz. Meryem, Lübnan nüfusunun ezici bir çoğunluğunu oluşturan Müslüman ve Hristiyanların tamamı için ortak bir kutsal kişidir. Ona hem Müslümanlar hem de Hristiyanlar ona büyük bir saygı duyarlar. Ayrıca her iki dinin kutsal anlatısına göre iktidar çatışmaları içerisinde oğlunun öldürülmesine tanıklık ederek yaşayabileceği en büyük acıları yaşamış bir kadındır. Filmde Meryem Ana görsellerine sıklıkla yer verilerek onun acısı ile günümüzde çocuklarını iktidar mücadelesinin en uç formu olan savaşlarda kaybeden kadınların acısı arasında bir benzerlik ilişkisi kurulduğu söylenebilir.

Labaki filminde Lübnan sinemasında çok sık işlenmeyen bir anlatıya yer vererek farklı dinlerin birlikte yaşamasının tesisi görevini kadın kahramanlara, özellikle de annelere yükler (Sinno, 2017). Kadınlar, anne ve eş rolleri verilerek toplumsal cinsiyet rol kalıplarına uygun şekilde konumlandırılsalar da, bu kalıpların öngördüğü şekilde pasif gözlemci ya da itaatkâr kurbanlar değillerdir. Kadınlar gördükleri ve duyduklarına göre hareket eder ve şiddetten kaçınan çözümler ararlar. Bu yapı Kinser'in (2010) da ifade ettiği gibi, anneliği, kadınların mutlak rolü olmaktan çıkarır ve onları bütün toplumsal aktörlerin dışına çıkaran ataerkil bir kuruma mahkûm etmek yerine, yeni feminist bir güç haline dönüştürür.

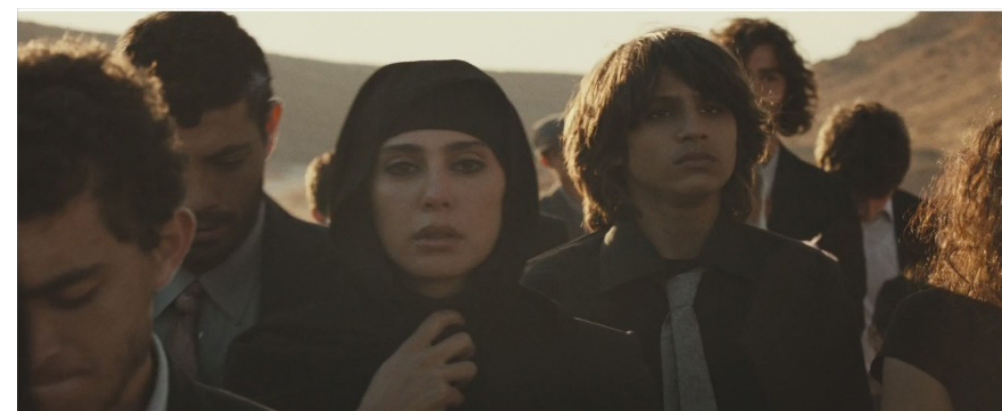

Görsel 5: Köy Halkının Birlikte Nassim'in Cenazesini Kaldırdığı Sahne

Peki Şimdi Nereye filminde de egemen sinema anlayışına uygun olarak fedakarlık yapma görevi kadınlara yüklenmiştir. Oğlu Naseem'in şehirden geri dönerken başıboş bir kurşunla vurulduğunu öğrenen Takla, büyük bir ıstırapla yıkılmasına rağmen bunu hem diğer oğlundan hem de köylülerden gizler ve oğlunun cenazesini bir kuyuya saklar. Söylemesi halinde oğlu İssam'ın, kardeşinin intikamını almak için köyün Müslümanlarından birisini öldürmesinden çekinmektedir. Naseem, köyün dışında Müslüman veya Hristiyan olduklarını bilmediğimiz kimliği belirsiz kişiler tarafından çapraz ateșe alınarak öldürülmüşse de, İssam'ın köydeki Müslümanları bu ölümden sorumlu tutacağını ve bu ölümün intikamını "onlardan" birini öldürerek alacağını tahmin etmektedir. Bu nedenle Naseem'in ölümünü gizlemeye çalışır ve acısını içinde atarak yeni bir çatışmanın ortaya çıkmaması için fedakârlık gösterir.

Peki Şimdi Nereye? filminin kadınlarının öyküsü ile Aristophanes'in savaşı taşladığı oyunu Lysistra'da anlatılan öykü benzerlik göstermektedir. Lysistra oyunu, feminist hareketin ilk eserlerinden birisi kabul edilmesi nedeniyle önemlidir. Lysistra'da kadınlar, Atina ve Sparta arasında yaşanan Peloponnesian savaşlarından bıkar ve erkeklerin savaşı sonlandırmaması durumunda onlarla cinsel ilişkiye girmeme kararı alırlar. Aristohanes bu eserinde yaşanan savaşın arkasında yatan mantıksız politik nedenleri eleştirir. Labaki ise erkeklerin politik veya dini nedenlerle savaşma isteklerinin hala sürüyor olmasını, sinema dilinin imkânlarını kullanarak benzer bir bakış açısıyla eleștirir. 


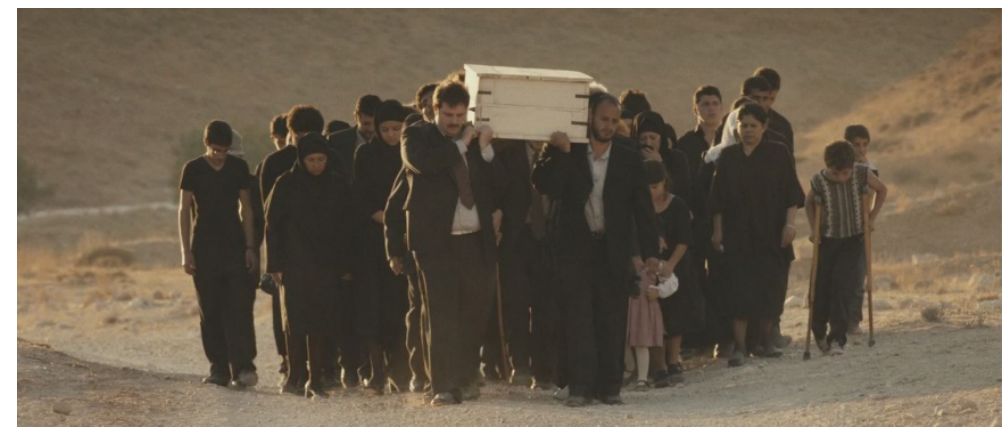

Görsel 6: Köy Halkının Birlikte Nassim'in Cenazesini Kaldırdığı Sahne - 2

Filmin sonunda, artık çatışmanın neredeyse kaçınılmaz olduğu bir anda kadınlar, giysilerini, ev dekorlarını, ibadetlerini; hatta inançlarını erkeklerin "öteki" olarak kabul ettiği şekilde değiştirirler. Kadınlar, evlerini erkeklerin kendilerini yabancı olarak bulacakları ve büyük bir şaşkınlık yaşayacakları yeni dinlerinin simgeleri ile dekore ederler. Bu durumun şaşkınlığını yaşayan erkeklerin, kadınlarla kavga ettikleri, yaşanan bu yeni durumu anlamaya çalıştıkları ve bilişsel uyumsuzluk algılarını çözme mücadelesi gösterdikleri sahneler, komik ve eğlenceli oldukları kadar keskin ve serttir. Kadınların yeni görünümleri ve davranışları, başlangıçta bu durumu delilikle ilișkilendiren erkeklerde büyük endișe yaratmıștır. Oysa kadınlar, görünüşte histerik kabul edilebilecek bu kararlarının maksatlı olduğunu savunmaktadırlar. Kadınlar; gelecekte "öteki" ile yaşanabilecek yeni çatışmaları engellemek ve hatta katliamları önlemek için "öteki" olmayı seçmişlerdir. Bu sayede her bir kadın, erkek için aslında "öteki” olmuştur ve eğer "öteki" ile bir çatışma yaşanacaksa önce erkeklerin kendi kardeşlerini, annelerini öldürmeleri gerekecektir.

Armes'e (2015, s. 234) göre Labaki bu filminde umutsuzca kadınların sürekli mücadeleye çözüm bulabileceklerini göstermenin bir yolunu bulmak istemektedir. Bunun için film boyunca Lübnanlı kadınların canlılı̆̆ını ve becerikliliğini kutlar; bununla birlikte, kadınların sorunu yalnız çözemeyeceğini itiraf etme dürüstlügüne de sahip bir yönetmendir.

\subsection{Kefernahum Filminin Çözümlenmesi Sonucunda Elde Edilen Bulgular}

Yönetmen Nadine Labaki'nin üçüncü uzun metraj filmi Kefernahum (Capharnaüm), ismini Celile Denizi batı kıyısındaki antik bir kentten alır. Aynı zamanda İncil'de gecen kutsal bir balıkçı köyünün ismi olan Capharnaüm (Smith ve Wace, 1877, s. 381-382; McClintock ve Strong, 1868, s.99-101), hem Yahudiler hem de Hıristiyanlar için değerli olan ve Kutsal Topraklardaki en iyi bilinen yerlerden biridir (Sapir ve Ne'eman, 1967). Kelime, Fransızca'da kaos ve karmaşa anlamlarına gelir. Labaki'nin anlattığı hikâye ise Lübnan'da geçer, film her karesiyle atıfta bulunduğu karmaşa ve kaosu izleyiciye duyumsatır.

Film, kız kardeşinin zorla evlendirildiği adamı bıçakladığı için beş yıl hapis cezasına mahkûm edilen Zain adlı on iki yaşındaki bir çocuğun, mahkemede ailesini dava etmesiyle başlar. Korku, öfke, şiddet, cahillik gibi çeşitli olumsuzluklarla örülü bir hayat yaşamak zorunda kalan Zain, onu hayata getirerek bu olumsuzlukları yaşamak zorunda birakan ailesinden davacıdır. Zain'in, hâkimin "Neden ailene dava açmak istiyorsun?" sorusuna verdiği "Beni dünyaya getirdikleri için" cevabı filmin en etkileyici diyaloglarından birisidir. Bu sahnenin hemen ardından Zain'i Lübnan sokaklarında görür, onu filmin açılışında yer alan mahkeme sahnesine getiren olayların nasıl başladığını öğrenmeye başlarız. 
Kız kardeşinin çocuk yaşta kendisinden çok daha yaşlı bir adamla zorla evlendirilmeye çalışılması üzerine Zain evden kaçar ve şehrin sokaklarında hayatta kalma mücadelesine girişir. Bu sırada kendisi de çeşitli zorluklarla mücadele etmekte olan Etiyopyalı bir göçmen bir kadın olan Rahil ve bebeği Yonas ile tanışır ve onlarla birlikte kalmaya başlar. Zain, Rahil ișe gittiği zamanlarda Yonas ile ilgilenmesi karşılığında bir yuva edinse de bu denge Rahil'in gözaltına alınması ve sınır dışı edilmesi tehlikesi ile karşı karşıya kalmasıyla bozulur. Artık oniki yaşında bir çocuk olan Zain, bir bebekle birlikte hayatta kalmaya çalışmaktadır. Bir süre sonra kız kardeşinin doğum sırasında öldügünü öğrenen Zain, kız kardeşinin zorla evlendirildiği erkeği öldürür ve hapsedilir. Ardından da kendisini dünyaya getirdikleri için ailesinden davacı olur.

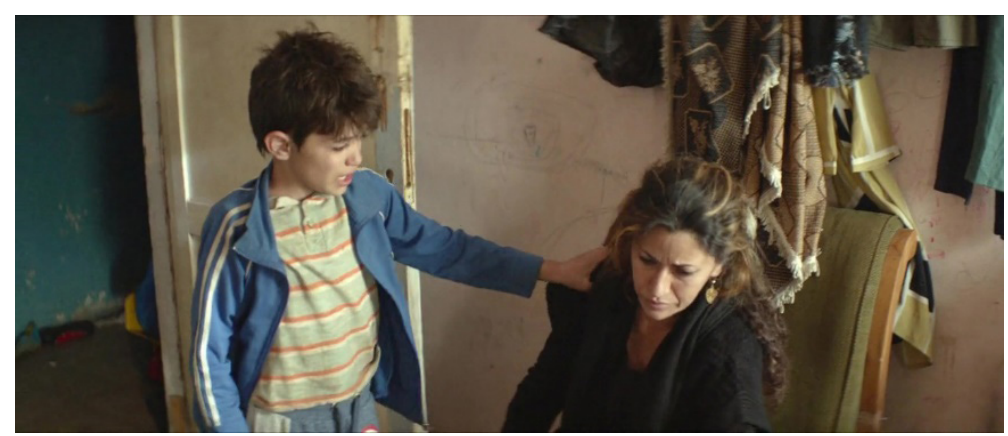

Görsel 7: Zain'in Kardeși Sahar'ın Doğum Sırasında Hayatını Kaybettiğini Öğrendiği Sahne

Zain, temel özellikleri ile dünyanın her yerinde karşılaşılabilecek sıradan bir çocuk prototipidir. İnsanları siyahi bir bebeğin abisi olduğuna annesinin çok kahve içtiği yalanıyla inandırabileceğini düşünecek kadar küçük ve saf bir çocuktur. Okula gitmek isteyen, lunapark görünce gideceği yeri unutup otobüsten inen bir çocuk... Öte yandan da kız kardeşi için mücadele edecek ve onu korumak için çabalayacak kadar sıra dışı bir çocuktur. Nadine Labaki; Zain ile ve diğer çocuk karakterle sokakta yaşamak zorunda kalan çocukların, çocuk gelinlerin, çocuk işçilerin, göçmen çocukların sorunlarını sinemaya aktarmaya çalışır ve anılan sorunları, Orta Doğu'nun kaotik siyasal ve toplumsal zemininde izleyiciye sunar.

Kefernahum, Ortadoğulu bir yönetmenin gözünden Ortadoğu'nun sosyal sorunlarına özellikle de kadınların ve kız çocuklarının yaşadığı sorunlara dikkat çeken bir filmdir. Filmde çeşitli kadın tiplerinin farklı sorunlarına yer verilmiştir. Bu kadın tiplerinin çeşitli zıtlıkları ifade edecek şekilde kurgulandığı söylenebilir. Daha iyi bir hayat umuduyla doğduğu yerden uzaklara gitmek zorunda kalmış, iyi kalpli, mülteci bir kadın olan Rahil karakterinin karşısına, düşüncesiz ve amaçsızca çocuk dünyaya getiren ve bunlara sahip çıkmayan bir anne karakteri olan Souad konumlandırılır. Souad, kızlarının genç yaşta evlendirilmesi noktasında eşinin kararını destekleyerek Sahar'ın ölümüne ve oğlunun katil olmasına zemin hazırlar. Labaki direnmeleri halinde kadınların birçok sorunun çözümünde etkili olabileceğini düşünen ve bu düşüncesini filmlerine yansıtan bir yönetmendir. Bu filmde de benzer bir yaklaşım sergileyerek bütün zorluklara rağmen mücadelesini sürdüren bir kadın olan Rahil'i, çocuğuna kavuşmasını sağlayarak ödüllendirirken; karşısına yerleștirdiği Souad'un pasifliğini, ona evlat acısı yaşatarak adeta cezalandırır. 


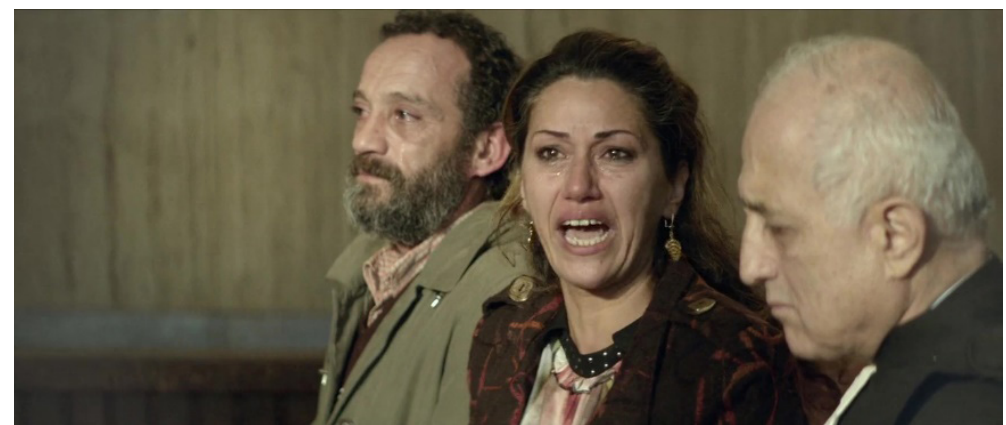

Görsel 8: Mahkemede Zain'in Annesinin Avukata (Nadine Labaki) Seslendiği Sahne

Yönetmen Nadine Labaki, kız kardeşinin zorla evlendirildiği kendisinden yaşça büyük eşini öldüren Zain'in avukatı rollünü üstlenerek Zain'in şahsında benzer durumdaki milyonlarca çocuğun savunucusu olduğunu açıkça ortaya koyar. Labaki'nin canlandırdığı avukat karakteri, iyi eğitim almış, başarılı bir kariyere sahip modern kadın imajının bir göstergesidir. Mahkeme sahnesinde Zain'in annesi Souad'un kadın avukata "Siz benim hayatımın ne zorluklarla geçtiğini nasıl bilebilirsiniz ki beni yargılayabilesiniz? Benim yerimde olsanız yaşamınızı sonlandırırdınız" sözleri ile seslenmesi, kadınların kapitalist, ataerkil sistem karşısındaki çaresizliğini ortaya koyar (Özdemir, 2020). Avukat rolündeki Labaki'nin bu sözleri karşısında cevap veremeyiși ya da vermeyişi, onun da bu çaresizliğin farkında olduğunu ve pasifliği nedeniyle suçladığı bu karaktere çok da kızamadığını göstermektedir. Bu konuşma aslında Ortadoğu'nun orta sinıflara mensup eğitimli kadınları ile eğitim imkânlarından mahrum alt sınıf kadınları arasındaki sınıfsal çelişkinin bir özeti gibidir.

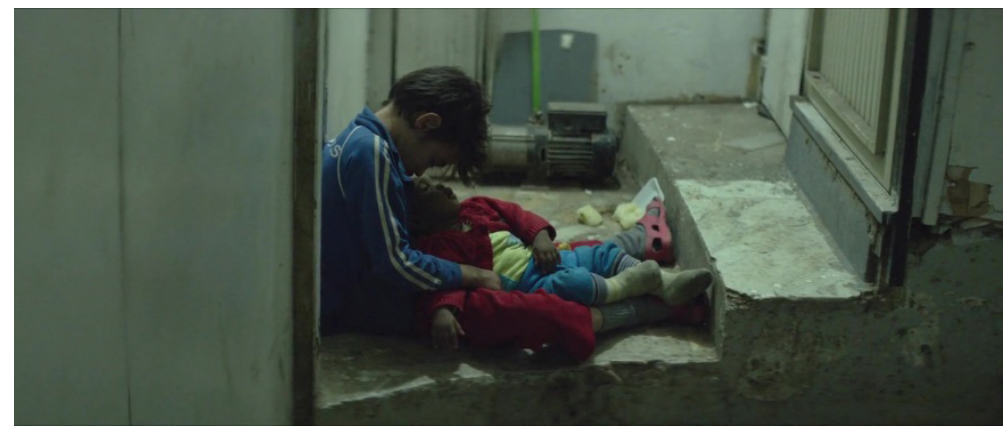

Görsel 9: Zain ve Yonas

Filmde işlenen önemli temalardan bir diğerinin ise genelde Ortadoğu'nun özelde ise Lübnan'ın yoksulluğudur. Yoksulluk teması; filmde işlenen diğer bütün temaların hem bir nedeni hem de bir sonucu olarak filmin ilk sahnesinden son sahnesine kadar vurgulanmıştır. Abisel'e göre (2005, s. 303) kadının toplumsal cinsiyet rolünün tanımlanması açısından yoksulluk önemli bir anlatısal araç olarak işlev görür. Çünkü yoksulluk, yaşama ilişkin beklentilerin, aşk, evlilik ve yuva özlemi dışına kayması, maddi olanakları genişletme ve refah içinde yaşama özleminin ön plana çıkması halinde, kadınların mutlu olma şansının nasıl ortadan kalkacağının gösterilmesine hizmet eder. Bu filmde de kızının evlenmesi sonucunda hem bir kişinin eksilmesi ile ekonomik olarak rahatlayacaklarını hem de kızının daha konforlu bir yaşama kavuşacağını umut eden Souad; kızının ölümüne, oğlunun da katil olmasına neden olarak Abisel'in tespitleriyle uyumlu şekilde mutlu olma şansını tamamen yitirir.

Yoksulluk yanında çok sayıda çocuğa sahip olmak Ortadoğu kadının temel sorunlarından birisidir. Ortadoğu'da kadınlar ortalama 45 yaşına kadar beş çocuk sahibi olmaktadır. Bu 
rakam tüm gelişmekte olan ülkelerdeki kadınların ortalamasından daha fazladır (AbiAad ve Grenon, 1997, s. 152). Ebevynlerin bakmakla yükümlü oldukları çocuk sayısının fazlalığı ile Ortadoğu toplumlarında yaşanan ekonomik, siyasi sorunlar, bir çatışmayı beraberinde getirmektedir. Souad'ın kızının çocuk yaşta evlenmesini istemesinin en önemli nedeni de evdeki çocuk sayısının fazlalığıdır. Kızının evlenmesiyle hane nüfusu bir kişi de olsa azalacaktır. Bununla birlikte Souad, yeni çocuklar doğurmaya devam eder.

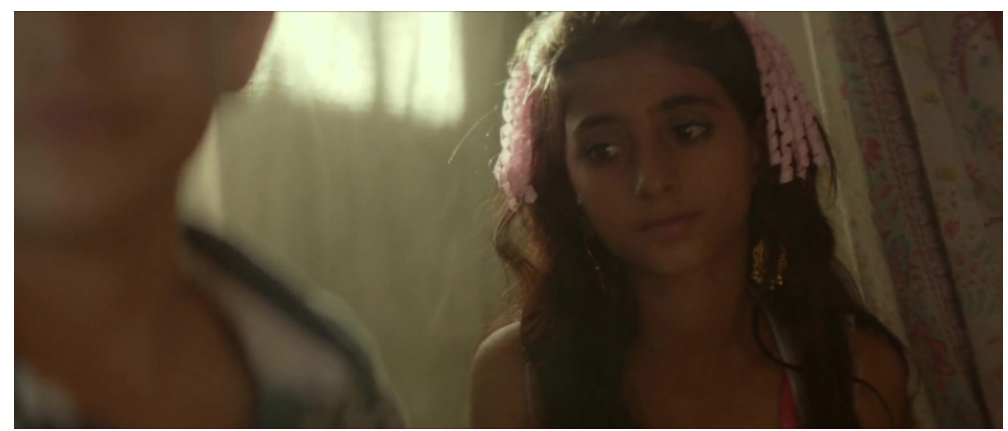

Görsel 10: Sahar İçin Görücü İçin Hazırlandı̆ğ Sahne

Çocuk gelinler Ortadoğu'nun en önemli kadın sorunlarından birisidir. Çocuk yaşta çoğu zorla ve kendisinden büyük erkeklerle yapılan evlilikler, kadının erken yaşta cinselliğe başlamasına ve çocuk sahibi olmasına bağlı birçok biyolojik sorunlar yanında eğitim alamama, kadının ekonomik özgürlüğünü kazanamaması, toplumdan dışlanma, eşinin ailesinden veya eşinden şiddet görme gibi çok çeşitli sorunlara da neden olmaktadır. Bu tür problemlerin cinsiyet eşitsizliğinin derin olduğu ataerkil toplumlarda erkeklerden daha çok kadınları etkilediği söylenebilir (Kaptanoğlu ve Ergöçmen, 2012). Cafernuhum filminde ana karakterimiz Sahar'da çocuk gelinlerin birçoğu ile aynı kaderi paylaşmış ve doğum yaptığı sırada vefat etmiştir.

Henüz ergenliğe girmiş bir kız çocuğu olan Sahar (Cedra İzam) filmin başlangıç bölümü dışında çok görünmese de oldukça önemli bir karakterdir. Onun ergenliğe girmiş olması ailesinin gözünde evlenmesi için yeterli olgunluğa ulaştığı fikrini doğurur, ailenin nüfusundan bir kişinin eksilmesi aile bütçesine faydalı olacağı, eşinin evinde daha iyi beslenebileceği gibi gerekçelerle evlendirilmesine karar verilir. Zain ise Sahar'ın evlendirilmesini istemez. Arkadaşları Alia'nın, iç çamaşırındaki kan lekesi fark edildikten sonra istemediği bir adamla evlendirilmesinden yola çıkarak aynı şeyi Sahar'a da yapacaklarını düşünür ve ailesi bu durumu fark etmesin diye önce kardeşinin iç çamaşırını yıkar; ardından da daha sonra kız kardeşinin zorla evlendirileceği adamın bakkalından kardeşi için ped çalar. Ancak ne kadar çaba sarf etse de kardeşinin evlendirilmesini engelleyemez ve Sahar'ın evden zorla götürülmesinin ardından evden kaçarak tek başına yaşamaya başlar. Filmin sonunda Sahar'ın evlendirildiği adamdan hamile kaldığını ancak çocuğu doğuramadan hayatını kaybettiğini öğreniriz.

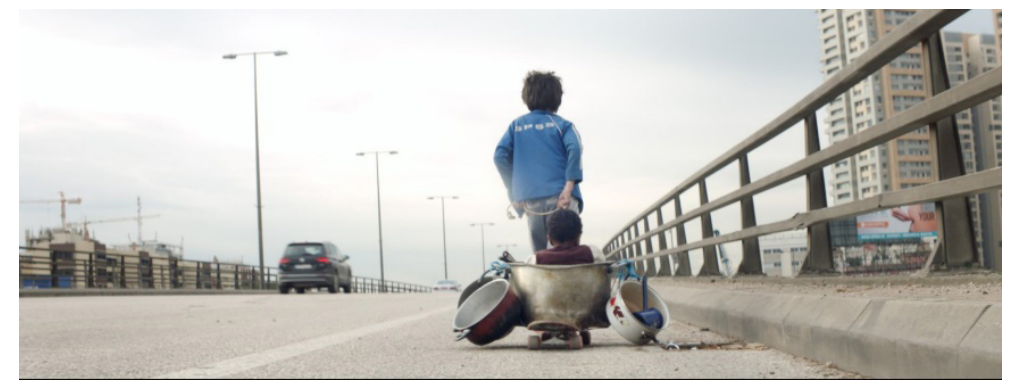

Görsel 11: Zain ve Yonas - 2 
Yaşamını zorluklar içerisinde sürdürmeye çalışan Etiyopyalı göçmen Rahil, bir diğer önemli kadın karakterdir. Labaki Rahil karakteri ile Lübnan'ın en önemli sorunlarından birisi olan göçü ve göçün getirdiği problemlerin en önemlilerden birisi olan kafala sistemini anlatısına dâhil eder. 2018 yılı verilerine göre 200.000'in üzerinde göçmen ev işçisi, kafala adı verilen bir sistemle Lübnan'da çalışmaktadır. Kafala sisteminde bir göçmenin ülkeden vize alabilmesi için ya o ülke vatandaşlarından ya da ülkede faaliyet gösteren şirketlerden birisinden davet alması gerekmektedir. Bu kişiler ülkeye gelince yanlarında çalışacakları vatandaşlar veya şirket pasaportlarını almakta ve o pasaportla bu kişilere "ikame" adı verilen çalışma ve oturma vizesini (kimlik) çıkartmaktadır. İkame belgesi çalışacak kimsede kalırken, kefil pasaportu himayesine almaktadır. Kişi, ülkeden çıkacağı zaman ikame belgesini işverenine teslim edip, temiz kâğıdı çıkartmakta ve bu temiz kâğıdıyla çıkış vizesi alıp, ülkeden ancak bu şekilde ayrılabilmektedir. Kişi pasaportunu tekrar alabilse bile çıkış vizesi olmadan ülkeden ayrılması oldukça zordur. Çılkış vizesinin uygulanmasındaki amaç; suç işleyen yabancıların ülkeden kaçmasına engel olmaksa da birçok problemi beraberinde getirmektedir. Filipinler, Etiyopya, Bangladeş, Sri Lanka ve Nepal gibi ülkelerden binlerce göçmen bu sistemle Lübnan'da çalışmaya devam etmektedir (Pande, 2013).

Bebeği ile birlikte hayata tutunmaya çalışan Rahil de kafala sistemi ile Lübnan'a gelen bir göçmendir. Labaki, Rahil karakteri aracılığı ile küreselleşmenin etkisiyle gittikçe daha önemli bir sorun haline gelen düzensiz göç sorununa ve çeşitli gerekçelerle doğduğu topraklardan ayrılmak zorunda kalan göçmen kadınların sorunlarına (Özdemir, 2019) değinir. Ayrıca karşılaştığı bütün zorluklara karşın çocuğuna veya evsiz kalmış başka bir çocuğa sahip çıkan bir karakter kurgulayarak fedakâr anne mitini de yeniden üretir.

\section{Sonuç}

Nadine Labaki, Lübnan'ın yetiştirdiği önemli yönetmenlerden birisidir. Kadın olması, eğitimini Lübnan'da tamamlaması ve filmlerini burada yapması, onu diğer Ortadoğulu yönetmenlerden ayırır. Labaki'nin filmlerindeki kadın temsilinin incelenmesi, kadın sorunlarının genelde Ortadoğu özelde ise Lübnan sinemasında nasıl işlendiğinin ortaya konulması açısından önemli veriler sunar. Bu çalışmada Labaki'nin çektiği üç uzun metraj film olan Karamel, Peki Şimdi Nereye ve Kefernahum filmlerinde kadınların ve kadın sorunlarının nasıl temsil edildiği analiz edilmiștir. Yapılan analizler sonucunda Labaki'nin kadın toplumsal cinsiyet rollerini sorunsallaştırmamakla birlikte aktif kadın karakterlere yer vererek klasik anlatı yapısından uzaklaştığı belirlenmiştir. Labaki, egemen sinema dilinin aksine erkekleri değil; kadınları kurtarıcı olarak konumlandırır.

Nadine Labaki'nin kadınlara yüklediği en önemli görev siyasal ve toplumsal barışın tesisidir. Kefernahum'da toplumsal barışın tesisi için kadınların, erkek egemenliğine karşı çocuklarının özellikle de kız çocuklarının yanında durmasının önemini belirten Labaki, Peki Şimdi Nereye? filminde ise siyasal barış için kadınların, acılarını yüreklerine gömmeleri gerektiğini, aksi halde her çatışmanın bir kan davasına dönüşerek barışı olanaksız kılacağını dolayısıyla da Lübnan'da ve Ortadoğu'da barışın mümkün olmayacağını vurgular. 0 , savaşın anlamsızlığını vurgulayarak hem hegemonik erkeklik değerlerini sorgulamaya açar hem de barışın tesisinin ancak kadınlar eliyle mümkün olabileceği tezini savunur.

İncelenen filmlerde geleneksel sinema anlatısında sıklıkla karşılaşılan birbirlerini çekemeyen veya çeşitli yol ve yöntemlerle sürekli olarak birbirlerine tuzaklar kuran kadın tiplerine rastlanmamıştır. Kadın karakterler özellikle Karamel ve Peki Şimdi Nereye 
filmlerinde dayanışma içerisindedir. Birlikte düşünüp, birlikte tartışıp, birlikte kararlar alırlar ve birlikte çözümler üretirler. Dayanışma içerisinde hareket etmeleri sayesinde kadın kimliklerinden vazgeçmeden mücadelelerini yürütürler ve başarılı olurlar. Kadının mücadelesini tek başına yürütmek zorunda kaldığı durumlarda ise bütün zorluklara rağmen vazgeçmeyen aktif kadınlar amacına ulaşır.

Ana akım sinemanın aksine Labaki sinemasında kadınlar yardımcı rollerde değildir. İncelenen bütün filmlerde başkahramanlar kadındır ve neredeyse bütün önemli roller kadınlar tarafından üstlenilmiştir. Ayrıca kadınlar olayların ya da erkeklerin kurbanları olmanın ötesinde eyleyen, kendi başlarına hayatta kalma veya duygularını yaşayabilme için mücadele eden, mevcut durumlarını değiştirme gayreti içerisinde olan aktif karakterlerdir. Kefernahum'da filmindeki Souad ve çocuk yaştaki Sahar dışında kaderine razı kadın tipine rastlanmaz.

Nadine Labaki, farklı ortam ve durumlarda kadın kimliklerini filmlerinde konu edinerek kadınların sorunları üzerinde durmuştur. Kadın kimlikleri perdeye yansıtılırken HristiyanMüslüman, eğitimli-eğitimsiz veya aktif-pasif gibi çeşitli ikilikler oluşturarak karakterini kurgulamıştır. Kurgulanan bu karakterler birbiriyle çatışmaz; hatta dayanışma içerisinde birlikte mücadele ederler. Gerilim anlarında dahi birbirine zarar vermezler. Örneğin Kefernahum'da Zain'in annesinin kadın avukatı hedef alan sözlerine avukat cevap vermez.

İncelenen filmlerde Karamel'in Rima'sı dışında eşcinsel karakterlere rastlanmaz. Hem kadınlar hem de erkekler toplumsal cinsiyet rol kalıpları içerisinde hareket ederler ve ataerkil düzenin ahlaki kodlarına uygun davranırlar. Aşkları ile aileleri ya da sorumlulukları arasında kaldıkları noktada ailelerini ya da sorumluluklarını tercih ederek aşklarından vazgeçerler. Labaki'nin kadınları toplumsal cinsiyet rol kalıpları ile uyumlu şekilde fedakâr karakterlerdir. Eşleri, özellikle de çocukları için kendi canlarını dahi tehlikeye atarlar. Bununla birlikte Labaki'nin kadınları ana akım sinemanın kadınlarına göre çok daha aktif ve mücadelecidir. Ayrıca duyguları ile değil akıllarıyla hareket ederler. Çocuklarını kaybettikleri anda dahi; çıkabilecek bir iç savaş engellemek için çocuklarının ölümünü bir süre saklamayı düşünecek kadar rasyonel bireylerdir.

Nadine Labaki kendisinin de içine doğduğu kaotik coğrafyanın sorunlarının çözümünde kadınların önemli roller oynayabileceğini düşünen bir yönetmendir. $\mathrm{Bu}$ düşüncesini de sinemasının temeline koyar. Bununla birlikte yaşanan sorunların temelinde yatan ekonomik nedenleri sorgulamaz. Sorunları kişiselleștirerek çözümleri basitleștirir. Hâlbuki Lübnan'ın ve Ortadoğu'nun sorunları, dolayısıyla bu coğrafyada yaşayan kadınların sorunları, bu sorunların temelinde yatan ekonomik ilişkiler göz önüne alınmadan çözülemez. Ekonomik sorunları görmezden gelmesi ve bunları sorunsallaştırmaması Labaki sinemasının en zayıf yönüdür. Nitekim onun filmleri klasik anlatı yapısına uygun şekilde katarsise imkân sağlayan eserlerdir. Filmin sonunda başta atılan düğümlerin neredeyse tamamı çözülür ve seyirciye rahatlama imkânı sağlanır.

Yapılan analizler sonucunda Labaki sinemasının toplumsal cinsiyet rol kalıplarını ve ataerkil ahlaki normları onayan bir yapıya sahip olmakla birlikte aktif, mücadeleci ve çözümler üreten kadın karakterlere yer vererek ana akım sinemadan farklılaştığı sonucuna ulaşılmıştır. Onun sinemasının kadınları, genellikle güçlü karakterlerdir ve çoğu zaman diğer kadınlarla dayanışma içerisinde, birlikte hareket ederek başarıya ulaşırlar; bu mümkün olmadığı durumlarda ise kaderlerine razı olmazlar ve mücadeleye devam ederler. Erkek egemenliğine boyun eğen pasif kadın karakterlerin ise genellikle kaybeden taraf olarak konumlandırılır. 


\section{Kaynakça}

Abi-Aad, N. ve Grenon, M. (1997). Instability and Conflict in the Middle East: People, Petroleum and Security Threats: Springer.

Abisel, N. (2005). Türk sineması üzerine yazılar: Phoenix.

Akyön, S. (2014). Pedro Almodovar Sinemasında Kadının Temsili. Ankara Üniversitesi İlef Dergisi, 1(2), 9-36.

Armes, R. (2010). Arab filmmakers of the Middle East: A dictionary: Indiana University Press.

Armes, R. (2015). New voices in Arab cinema: Indiana University Press.

Balaa, L. (2019). Framed: The Door Swings Both Ways in the Lebanese Movie Caramel Directed by Nadine Labaki, Produced by Anne-Dominique Toussaint; Written by Nadine Lebaki, Rodney El Haddad, Jihad Hoiely. Sunnyland Films, Lebanon, May 2007. Running time 96 minutes. Journal of International Women's Studies, 20(7), 428-445.

Bayraktar, R. ve Uçanok, Z. (2002). Menopoza ilişkin yaklaşımların ve kültürlerarası çalışmaların gözden geçirilmesi. Sosyal Politika Çalışmaları Dergisi, 5(5).

Cestor, E. (2010). Music and media in the Arab world (No. 4108-4109) (M. A. Frishkopf Ed.): American Univ in Cairo Press.

Demir, K. N. (2008). Savaş Filmlerinde Kadın Temsilleri. Communication in Peace/Conflict in Communication, Kibris: Eastern Mediterranean University Press. Editör: Turgut Ilter $v d, 177-185$.

Erus, Z. Ç. ve Gürkan, H. (2012). Toplumsal cinsiyet ve sinemaya yansıması: yeniden çekimler aracılığıyla Japon ve Amerikan sinemalarında kadının temsiline bir bakış. Selçuk İletişim, 7(3), 206-217.

Ginsberg, T. ve Lippard, C. (2010). Historical dictionary of Middle Eastern cinema: Scarecrow Press.

Gugler, J. (2015). Ten Arab Filmmakers: Political Dissent and Social Critique: Indiana University Press.

Héritier, F. (2013). Kadınların en güzel tarihi: Türkiye İş Bankası Kültür Yayınları.

Hornaday, A. (2012). Nadine Labaki on 'Where Do We Go Now?' and the absurdity of war. The Washington Post.

İnceoğlu, İ. (2015). Beyaz perdede kadın anlatısı: Mavi Dalga filminin feminist incelemesi. Fe Dergi, 7(2), 87-94.

Kaptanoğlu, İ. Y. ve Ergöçmen, B. A. (2012). Çocuk gelin olmaya giden yol. Sosyoloji Araştırmaları Dergisi, 15(2), 128-161.

Khatib, L. (2008). Lebanese cinema: imagining the civil war and beyond. Londra: I. B. Tauris.

Kinser, A. E. (2010). Motherhood and feminism: Seal studies: Seal Press.

Labaki, N. (2012) A Conversation with Nadine Labaki (Capernaum)/Interviewer: C. Reed. https://www.hammertonail.com/shorts-contest/nadine-labaki-interview/. 
Mouawad, W. (2020). Lebanese Cinema and the French Co-production System: The Postcard Strategy. In C. L. Terri Ginsberg (Ed.), Cinema of the Arab World: Contemporary Directions in Theory and Practice (pp. 71-87): Springer Nature.

Mulvey, L. (1997). Görsel Haz ve Anlatı Sineması, Nilgün Abisel (çev), 25. Kare. 21. 38-46.

Özdemir, E. (2019). Eleştirel Güvenlik Yaklaşımları ve Uluslararası Göç. In M. Görgün (Ed.), Uluslararası Göç (pp. 168-182). İstanbul Beta Yayınları.

Özdemir, E. (2020). Visible and Invisible Borders around Women: Feminist Meaning of War and Migration in Cinema. ARTS: Artuklu Sanat ve Beşeri Bilimler Dergisi, 3, 57 63.

Pande, A. (2013). "The paper that you have in your hand is my freedom": Migrant domestic work and the sponsorship (Kafala) system in Lebanon. International Migration Review, 47(2), 414-441.

Sapir, B. ve Ne' eman, D. (1967). Capernaum (Kfar Nachum). History and Legacy, Art and Architecture Tel Aviv.

Sinno, N. (2017). "May the War be Remembered but Not Repeated": Engendering Peace in Nadine Labaki's Where Do We Go Now? College Literature, 44(4), 615-643.

Smith, S. (1993). Kadının Sinemadaki İmajı. 25. Kare, 6, 19-24.

Smith, W. ve Wace, H. (1877). A Dictionary of Christian Biography, Literature, Sects and Doctrines: Being a Continuation of'The Dictionary of the Bible' (Vol. 1): J. Murray.

Stoller, R. J. (2020). Sex and Gender: The Development of Masculinity and Femininity: Routledge.

Taubin, A. (2008). Caramel: Film Comment. New York, pp. 70-71.

www.jstor.org/stable/43458902, Erişim Tarihi 10.02.2020 


\title{
Represantation of Women in the Cinema of Nadine Labaki
}

\author{
Emre Așilığlu (Asst. Prof. Dr.) \\ Mehmet Işık (Assoc. Prof. Dr.)
}

\section{Extended Abstract}

In the Middle East, where women are exposed to various discriminations in all areas of social life, woman filmmakers are very few. Limited educational opportunities and social gender inequality, which obstructs women in almost all areas of social life, prevent prospective woman directors from receiving an adequate education. Nadine Labaki, one of the rare Middle Eastern woman directors in recent years, becomes a unique example in this sense with her successful films. It makes her even more remarkable that Labaki was born and raised during the Civil War and completed her entire educational carrier, including the university in Lebanon.

She is separated from other Middle East directors in that she is a woman who completed her education in Lebanon and made her films there. Analyzing female representation in Labaki's films reveals important data in terms of how women's problems are handled in the Middle East in general and in Lebanese cinema in particular. In this study, how women and problems of women are represented in Labaki's three full-length films, Caramel (2007), Where Do We Go Now? (2011), and Capernaum (2018) are examined. As a result of the analysis, it is determined that Labaki does not problematize female social gender roles, but she diverts from the classical narrative structure by emphasizing active woman characters in her films. On the contrary to the dominant cinema language, Labaki puts women in the position of saviour rather than men.

The most important duty that Nadine Labaki gives women is the establishment of political and social peace. Labaki stated that it is crucial for women to stand by their children, especially daughters, against male domination to establish social peace in Capernaum. In Where Do We Go Now?, she emphasizes that women should bury their suffering into their hearts for political harmony; otherwise every conflict will turn into a feud and make peace impossible for Lebanon and the Middle East. She emphasizes the stupidity of the war, and not only questions hegemonic manhood values but also defends the fact that the establishment of peace is only possible with women.

In the analyzed films, there are no types of women like the ones frequently encountered in traditional cinema narratives, who don't get along or regularly trap each other in different ways and methods. Female characters, especially in Caramel and Where Do We Go Now? are in solidarity. They think together, argue together, decide together, and create solutions together. Due to acting in solidarity, they struggle without losing their female identities, and they succeed. In the cases where the women must fight on their own, the active women, who don't give up, reach their aims against all the odds.

On the contrary to the mainstream cinema, female characters are not in the supporting roles in Labaki's films. In all the analyzed films, the main characters are women, and almost all the critical roles are acted by women. Besides, women are active characters, who are not victimized by events or men. They struggle to survive on their own or live their feelings and strive to change their status. In Capernaum, no woman is satisfied with their fate except Souad and Sahar. 
Nadine Labaki emphasizes female problems by discussing female identities in various settings and cases in her films. She fictionalized characters by creating various dichotomies like Christian-Muslim, educated-uneducated or active-passive. These fictionalized characters do not conflict with one other; even they struggle together in solidarity. Even in times of tension, they do not harm one other. For example, in Capernaum, the lawyer does not reply to the words of Zain's mother targeting a female lawyer.

In the analyzed films, there are not any homosexual characters except Caramel's Rima. Both women and men act according to social gender roles and behave in conformity with moral codes of patriarchy. When they remain between their loves and families or responsibilities, they choose their families or responsibilities. Labaki's women are selfsacrificing characters who are compatible with social gender role models. They even risk their lives for their husbands and especially for their children. However, Labaki's women are more active and combative in comparison with female characters of mainstream cinema. Also, they act with their minds, not with their emotions. Even when they lose their children, they are rational enough to think to hide their children's death for a while to prevent a civil war that may arise.

Nadine Labaki is a director who thinks that women can play important roles in the solution of the problems of the chaotic geography in which she was born. She puts this thought on the basis of her films. In the meantime, she does not question the economic reasons underlying the problems. She simplifies the solutions by personalizing the difficulties. However, the challenges of Lebanon and the Middle East, and therefore the struggles of women living in this geography, cannot be solved without considering the economic relations underlying these problems. Ignoring economic problems and not problematizing them is the weakest aspect of Labaki's cinema. As a matter of fact, her films are works that enable catharsis compatible with classical narrative structure. At the end of the film, almost all the nodes tied at the beginning are disentangled, and the audience is given the opportunity to relax.

As a result of the analyses, it is concluded that although the films have similar features with mainstream cinema in that they approve gender-role patterns and patriarchal moral codes, they differ from mainstream cinema films by giving place to active, combative, problem-solver female characters. It is determined that the women in the analyzed films are generally strong characters and they often succeed in solidarity with other women by acting together; in cases where this is not possible, they do not accept their destiny, and they struggle; passive female characters, who are submissive to male domination, are generally positioned as the losing side. Besides, it is determined that the economic causes of women's problems handled throughout the films are not emphasized, and the problems are made easy to solve by individualizing them.

Keywords: Cinema, Lebanese Cinema, Nadine Labaki, Woman, Caramel (2007), Where Do We Go Now? (2011), Capernaum (2018). 